\title{
Dispatches from the Editor: Is the end of the print military medical journal inevitable?
}

As editor in chief, I recently attended a course run by Pippa Smart for newly appointed medical editors. With 26 editors and publishers ranging from the $B M J$, Elsevier, Wiley and Cambridge University Press as well as most medical disciplines present, it was a good representation of contemporary publishing. It identified many of the shared challenges we have with other journals but also how unique in many ways we as the Journal of the Royal Army Medical Corps are. I'm going to take a different approach to my predecessor and instead of using the introductory page in every edition of the journal to identify just the highlights of the edition, I intend to identify some of the changes and decisions being made at the journal and relate them to the wider context of medical publishing. This will include challenges faced by all journals such as chasing the impact factor, improving journal access for subscribers, open access publishing and obtaining rapid and constructive peer review. I will also address challenges more specific to our military journal in terms of ethics, security clearance, the use of social media and producing a single journal truly

Correspondence to Major Johno Breeze, Academic Department of Military Surgery and Trauma, Royal Centre for Defence Medicine, Birmingham B15 2SQ, UK: editor.jramc@bmj.com representative of all three services and all medical disciplines.

In this editorial, I will focus on the manner in which JRAMC is distributed. Of the 26 journals represented in my recent course, only 10 were still in print, with the remainder being online only. In addition, a further three were intending to become electronic only and most newly formed journals are online only. This supports a comprehensive survey that demonstrated that print only sales dropped from $88 \%$ to $34 \%$ between 1998 and 2011, whereas electronic only sales rose from $4 \%$ to $50 \%$ in the same period. ${ }^{1}$ And that was 6 years ago. Reasons cited for being online only include reduced costs, reduced distribution times and increased visibility. Although it is difficult to argue the first point, the other two do not hold up in the modern publishing environment used by JRAMC. Our papers are published online only first almost immediately post acceptance and we are incorporated into an extensive network of media and online promotion of content published in $B M J$ journals.

At the start of my tenure in June 2017, the editorial board, in conjunction with reader feedback, decided to continue distributing the journal in print form and this was supported by the journal's management board. All content distributed in paper format is available electronically and some components such as case reports will increasingly only be available online. However, nothing is forever and there may come a time where online only publishing will have become the accepted norm. As always we will survey our subscribers and respond to their wishes. Whatever the outcome, we must retain our heritage and reputation, for at this course the JRAMC was the oldest of the journals. However, it will be a shame not to have the paper copy of the journal land on my doorstep every other month.

\section{Competing interests None declared.}

Provenance and peer review Not commissioned; internally peer reviewed.

(C) Article author(s) (or their employer(s) unless otherwise stated in the text of the article) 2017. All rights reserved. No commercial use is permitted unless otherwise expressly granted.

To cite Breeze J. J R Army Med Corps 2017;163:365.

J R Army Med Corps 2017;163:365

doi:10.1136/jramc-2017-000885

REFERENCE
1 EBSCO Information Services. Library collection and
budgeting trends survey, 2011. 